

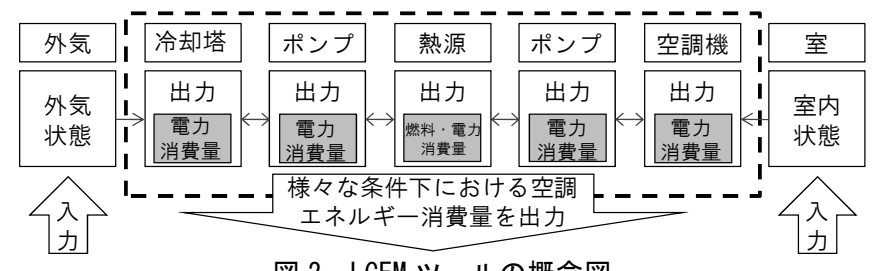

図 2 LCEM ッールの概念図

\section{3. 主な計算アルゴリズムの比較}

DeST と LCEM ツールの主なモデルの計算アルゴリズムを比較する。

\section{1 熱源機器}

DeST では、機器の出力とエネルギー消費量は負荷率、外気条件や 冷水温度などの性能パラメーターを独立変数とする式(1)のような 特性式で算定される。

$$
(Q, E)=f\left(P L R, t_{a, i n} / t_{w, i n}, W\right) \quad \cdots(1)
$$

LCEM ツールでは、DeST と同様に特性式を用いてエネルギー消費量 が算出される。電動冷凍機や直だき吸収冷温水機の冷却運転時の工 ネルギー消費量を算出する特性式を式(2)、式(3) に示す。冷却水入 口温度、冷水出口温度、部分負荷率、冷却水量、冷水量の関数であ る 5 つの影響係数 $\mathrm{C} 1$ 〜 5 による性能特性を考慮したモデルとなっ ている。

$$
\begin{aligned}
& E=e E_{\text {rated }} \\
& e=C_{1} C_{2} C_{3} C_{4} C_{5}
\end{aligned}
$$

\section{2 冷却塔}

DeST の冷却塔出口水温は式(4)でされる。送風機動力は式 (5)で算 出され、制御方法によって異なる。

$$
\begin{aligned}
& t_{c w, o u t}=f\left(P L R, G, W, t_{w b, O A}\right) \\
& E=f(\text { ControlStrategy })
\end{aligned}
$$

一方で、LCEM ツールの冷却水往温度は、式(6)で計算される。

$$
t_{c w, o u t}=f\left(W, t_{c w, i n}, t_{w b, O A}\right)
$$

冷却塔の送風機の消費電力量は、運転中は定格出力で一定としてい る。冷却水下限值制御を行う場合には、送風機を発停させて運転す

る。この場合、送風機の定格出力に式(7)の係数を乗ずる。

$$
C_{t P W}=\left(t_{c w, i n}-t_{c w, s e t}\right) /\left(t_{c w, i n}-t_{c w, f}\right)
$$

\section{3 送風機・ポンプ}

DeST の送風機・ポンプの特性は、式(8)で定義される。

$$
E=f(\eta, G \text { or } W, \text { freq }, H)
$$

ここで、 $\eta$ は送風機・ポンプの効率である。LCEM ツールも同様の考 え方であるが、効率 $\eta$ は変動せず一定である。

\section{4 冷却・加熱コイル}

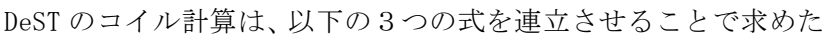
い状態值（例えば空気の出入口温度、風量、入口水温が既知で、出 口水温と流量を求める）を算出する。

$$
\left\{\begin{array}{l}
E_{g}=\frac{1-\exp [-\beta(1-\gamma)]}{1-\gamma \exp [-\beta(1-\gamma)]}=\frac{t_{1}-t_{2}}{t_{1}-t_{w 1}} \\
E^{\prime}=1-\exp \left[\left(-\alpha_{w} \cdot a \cdot N\right) /\left(V_{y} \rho C_{p}\right)\right]=1-\frac{t_{2}-t_{2 S}}{t_{1}-t_{1 S}} \\
G\left(i_{1}-i_{2}\right)=W C\left(t_{w 2}-t_{w 1}\right)
\end{array}\right.
$$

ここで、 $\beta=\frac{K_{s} F}{\xi G C_{p}} 、 \gamma=\frac{\xi G C_{p}}{W C} 、 V_{y}=\frac{G}{F_{y} \rho} 、 \xi=\frac{i_{1}-i_{2}}{C_{p}\left(t_{1}-t_{2}\right)}$ 、
$K_{s}=\left[\frac{1}{B \cdot V_{y}^{m} \xi^{P}}+\frac{1}{D \cdot \omega^{n}}\right]^{-1}$ であり、パラメータは型番ごとに既知の值と なる。

LCEM ツールでは、コイルの列数を既知としてコイル入口側と出口 側の空気条件より、冷水量と冷水出口温度を求める。冷水量は、式 （10）に示寸濡れ面係数法により求められる交換熱量が、式 (11) に示す空気側の交換熱量と一致するよう収束計算により求める。な お、冷水出口温度は冷水量が決まれば従属的に決まる。

$$
\begin{aligned}
& Q_{t}=W S F \cdot K f \cdot F_{y} \cdot N \cdot M T D \\
& Q_{a}=G\left(i_{1}-i_{2}\right)
\end{aligned}
$$

3.5 ファンコイルユニット (FCU)

DeST では、FCU 系統内の配管内圧力損失と各 FCU にかかる負荷を 考慮して流量を算出する。FCU の送風機は処理する負荷が無い時間 を除き常に一時間定格運転される。

LCEM ツールでは、要求負荷に対する FCU の処理能力の比率から運 転時間を決定する。なお、同一系統の FCUは、全台数同じ運転とな る。水量と出口水温は、負荷が下限出力值になるまで二方弁が比例 制御されると想定し計算される。その時間中は全 FCU の送風機は定 格で運転される。

\section{6 給気温度および風量の設定}

1）定風量方式の計算アルゴリズム

DeST では、1 つの空調機に接続される複数の室の給気温度は式 (12)で表現される。

$$
\begin{gathered}
t_{k, \text { supply }}(\tau) \in\left(t_{k, \text { set, } \min }(\tau)+\frac{t_{k, \text { set, min }}(\tau)-\hat{t}_{k}(\tau)}{A G_{k}(\tau)},\right. \\
\left.t_{k, s e t, \text { max }}(\tau)+\frac{t_{k, \text { set, } \max }(\tau)-\hat{t}_{k}(\tau)}{A G_{k}(\tau)}\right), A=\psi C_{p} \rho
\end{gathered}
$$

各室の給気温度が同じであるには、式(13)を満足する必要がある。

$$
t_{\text {system,supply }}(\tau) \in \Omega_{t, \text { system }}(\tau)=\bigcap_{k}\left(t_{k, \text { supply, min }}(\tau), t_{k, \text { supply,max }}(\tau)\right)
$$

ここで、 $\Omega_{t, \text { system }}(\tau)$ は $\tau$ 時刻に空調機に要求される給気温度の範囲 である。ある時刻に $\Omega_{t, \text { system }}(\tau)$ が存在しなければ、その時刻では 全室の温・湿度の要求条件は満足できないことになる。 $\Omega_{t, s y s t e m}(\tau)$ が存在する場合には、コイル負荷が最少となる給気温・湿度が決定 される。室温の計算吹出し温度が決まれば、室温は式(14)で計算さ れる。

$$
t_{k}(\tau)=\frac{\hat{t}_{k}(\tau)+A G_{k}(\tau) \cdot t_{\text {system, supply }}(\tau)}{1+A G_{k}(\tau)}
$$

LCEM ツールでは、最大風量を給気風量として室の顕熱負荷と基準温 度から要求給気温度を式(15)により算出する。

$$
t_{r, \text { supply }}(\tau)=t_{r}(\tau)-Q_{s}(\tau) / C_{p} G_{\max }
$$

要求給気温度が給気温度と異なる場合には、この差を不足温度とし て算出する。室温は、室負荷と給気風量、給気状態から式(16)によ り算出する。

$$
t_{r}(\tau)=t_{\text {supply }}(\tau)+Q_{s}(\tau) / C_{p} G_{\max }
$$

2）変風量方式の計算アルゴリズム

DeST では、給気温度は、式(17)～(19) で示されるように給気量範 囲と室内設定温・湿度範囲を総合的に考慮し吹出し温度を決める。

$$
\begin{aligned}
& t_{k, \text { supply }}(\tau) \in\left(t_{k, \text { supply,min }}(\tau), t_{k, \text { supply,max }}(\tau)\right) \\
& t_{k, \text { suppl } y, \text { max }}(\tau)=\operatorname{MAX}\left(t_{k, s e t, \text { min }}+\frac{t_{k, \text { set, } \min (\tau)}-\hat{t}_{k}(\tau)}{A G_{k, \text { min }}}, t_{k, \text { set, min }}+\frac{t_{k, s e t, \text { min }}(\tau)-\hat{t}_{k}(\tau)}{A G_{k, \text { max }}},\right.
\end{aligned}
$$




$$
\begin{aligned}
& \left.t_{k, s e t, \text { min }}+\frac{t_{k, s e t \text {, max }}(\tau)-\hat{t}_{k}(\tau)}{A G_{k, \text { min }}}, t_{k, s e t \text {,min }}+\frac{t_{k, s e t, \text { max }}(\tau)-\hat{t}_{k}(\tau)}{A G_{k, \text { max }}}\right) \\
& t_{k, \text { supply,min }}(\tau)=\operatorname{Min}\left(t_{k, \text { set, } \min }+\frac{t_{k, s e t, \min (\tau)}-\hat{t}_{k}(\tau)}{A G_{k, \min }},\right. \\
& t_{k, s e t, \text { min }}+\frac{t_{k, s e t \text {, min }}(\tau)-\hat{t}_{k}(\tau)}{A G_{k, \text { max }}}, t_{k, \text { set, } \text { min }}+\frac{t_{k, s e t, \text { max }}(\tau)-\hat{t}_{k}(\tau)}{A G_{k, \text { min }}} \\
& \left., t_{k, s e t, \text { min }}+\frac{t_{k, s e t \text {, max }}(\tau)-\hat{t}_{k}(\tau)}{A G_{k, \text { max }}}\right)
\end{aligned}
$$

そして、式(13)より給気温度を計算する。部屋の給気量の計算は、 式 (20)、(21)より室温の上限・下限值に応じて給気量を求める。

$$
\begin{aligned}
G_{k, \text { cal,min }}(\tau) & =\frac{t_{k, \text { set,min }}(\tau)-\hat{t}_{k}(\tau)}{A\left(t_{k, \text { supply }}(\tau)-t_{k, \text { set, min }}(\tau)\right)} \\
G_{k, \text { cal,max }}(\tau) & =\frac{t_{k, \text { set,max }}(\tau)-\hat{t}_{k}(\tau)}{A\left(t_{k, \text { supply }}(\tau)-t_{k, \text { set,max }}(\tau)\right)}
\end{aligned}
$$

また、送風機の消費エネルギーを最少にするように、式(22)により $\tau$ 時刻の室への給気量を計算する。

$$
G_{k}(\tau)=\operatorname{MIN}\left(\left(G_{k, c a l, \text { min }}(\tau), G_{k, c a l, \text { max }}(\tau)\right) \cap\left(G_{k, \text { min }}, G_{k, \text { max }}\right)\right.
$$

室温は定風量方式と同様に、式(14)で計算される。

LCEM ツールでは、給気温度を一定として、室の顕熱負荷と室温設 定值から要求風量を算出し、式(23)により給気風量を決定する。

$$
G(\tau)=Q_{s}(\tau) /\left\{C_{p} \cdot\left(t_{r}(\tau)-t_{\text {supply }}\right)\right\}
$$

算出した給気風量が最大風量を上回る場合には、給気風量を最大風 量として不足風量を算出する。要求風量が最少風量を下回る場合に は、給気風量を最少風量として不足風量を算出する。室温は、室負 荷と給気風量、給気状態から式(24)により算出する。

$$
t_{r}(\tau)=t_{\text {supply }}+Q_{s}(\tau) / C_{p} G(\tau)
$$

以上より、両ツールの主な計算アルゴリズムの比較を行った。各 設備機器の特性式は計算アルゴリズムの違いによって異なる点もあ るが、考慮する特性パラメーターの種別には大差はない。

\section{4. 計算可能なシステムと制御方法の比較}

\section{1 シミュレーション可能なシステム}

表-1 にDeST、LCEM ツールにて取り扱い可能な熱源機器、空調機 器および搬送系の各システムを示す。

\section{2 シミュレーション可能な制御方式}

表-2 に両ツールの各制御方式の、表-3 に熱源台数制御方式の、表 -4 に空気調和機の給気温度・湿度制御方式の、表 -5 に外気導入制御 方式の対応状況を示す。表より、両ツールとも一般的な空調システ ムの制御方式はシミュレーション可能であるが、一部、対応可能な 制御方式に異なる点も見受けられる。

\section{5. モデル建物におけるシミュレーション結果の比較}

\section{1 比較検証の手順と境界条件の設定}

各構成要素の性能や特性を整合させシミュレーションを行い、両

\begin{tabular}{|c|c|c|c|c|}
\hline \multirow[t]{2}{*}{ 区分 } & \multicolumn{2}{|c|}{ 機器名・項目 } & LCEM & DeST \\
\hline & \multirow{2}{*}{ 冷凍機 } & 遠心冷凍機 & 0 & $\mathrm{O}$ \\
\hline \multirow{15}{*}{ 熱源 } & & 蒸気吸収冷凍機 & 0 & $\mathrm{O}$ \\
\hline & \multicolumn{2}{|c|}{ 空冷熱源ヒートポンプ } & $\mathrm{O}$ & $\mathrm{O}$ \\
\hline & \multirow{2}{*}{$\begin{array}{l}\text { 吸収式 } \\
\text { 冷温水機 }\end{array}$} & ガスだき & 0 & O \\
\hline & & 排熱投入 & 0 & $x$ \\
\hline & \multicolumn{2}{|l|}{ チラー } & 0 & ○ \\
\hline & \multicolumn{2}{|c|}{ ブラインチラー } & 0 & $\bigcirc$ \\
\hline & \multicolumn{2}{|c|}{ スクリュー泠凍機 } & $\mathrm{O}$ & $\mathrm{O}$ \\
\hline & \multicolumn{2}{|c|}{ 温水発生機 } & 0 & O \\
\hline & \multicolumn{2}{|c|}{ 蒸気ボイラー } & $\mathrm{O}$ & O \\
\hline & \multirow{2}{*}{ 水蓄熱 } & 温度成層型 & 0 & \multirow{4}{*}{ 開発中 } \\
\hline & & 連結式完全混合型 & 0 & \\
\hline & \multirow{2}{*}{ 水蓄熱 } & 内融式 & O & \\
\hline & & 外融式 & 0 & \\
\hline & \multirow{2}{*}{ 冷却塔 } & 開放型 & $\mathrm{O}$ & $\mathrm{O}$ \\
\hline & & 密閉型 & 0 & O \\
\hline 搬送系 & \multicolumn{2}{|c|}{ ポンプ } & $\mathrm{O}$ & $\mathrm{O}$ \\
\hline \multirow{5}{*}{$\begin{array}{l}\text { 空気 } \\
\text { 調和機 }\end{array}$} & \multicolumn{2}{|c|}{ 空気調和機（ユニット/コンパクト） } & 0 & 0 \\
\hline & \multicolumn{2}{|c|}{ ファンコイルユニット } & 0 & O \\
\hline & \multirow{2}{*}{\multicolumn{2}{|c|}{$\begin{array}{l}\text { デシカント空調機 } \\
\text { 送風機 }\end{array}$}} & $\mathrm{O}$ & $\mathrm{O}$ \\
\hline & & & $\bigcirc$ & $\bigcirc$ \\
\hline & \multicolumn{2}{|c|}{ 全熱交換機 } & 0 & 0 \\
\hline
\end{tabular}
者のエネルギー消費やシステム動作を比較検証した。比較検証を行 うための手順を図-3に示す。また境界条件を下記のように設定した。

\begin{tabular}{|c|c|c|c|c|}
\hline \multicolumn{3}{|c|}{ 制御方式 } & LCEM & DeST \\
\hline \multirow{3}{*}{$\begin{array}{l}\text { 給気 } \\
\text { 還気 }\end{array}$} & 定風量 & & $\mathrm{O}$ & $\mathrm{O}$ \\
\hline & \multirow{2}{*}{ 変風量 } & 回転数制御 (定圧) & 0 & 0 \\
\hline & & 回転数制御 (変静圧) & $\mathrm{O}$ & 0 \\
\hline \multirow{3}{*}{$\begin{array}{l}1 \text { 次 } \\
x^{*} ン 7^{\circ}\end{array}$} & 定流量 & バイパス制御なし & O & 0 \\
\hline & \multirow{2}{*}{ 変流量 } & 回転数制御（定圧） & 0 & 0 \\
\hline & & 回転数制御 (最小吐出圧) & $\mathrm{O}$ & $\mathrm{O}$ \\
\hline \multirow{10}{*}{$\begin{array}{l}2 \text { 次 } \\
\text { ポンプ }\end{array}$} & 定流量 & & $\bigcirc$ & $\mathrm{O}$ \\
\hline & \multirow{3}{*}{$\begin{array}{l}\text { 変流量 } \\
\text { (並列絞り 運転) }\end{array}$} & 回転数+バイパス制御（定圧） & O & O \\
\hline & & 回転数制御 (定圧) & O & O \\
\hline & & 回転数制御 (最小吐出圧) & $\mathrm{O}$ & $\mathrm{O}$ \\
\hline & \multirow{3}{*}{$\begin{array}{l}\text { 変流量 } \\
\text { (台数制御 } \\
\text { +並列絞り運転) }\end{array}$} & 回転数+バイパ ス制御（定圧） & $\mathrm{O}$ & $\mathrm{O}$ \\
\hline & & 回転数制御 (定圧) & 0 & 0 \\
\hline & & 回転数制御 (最小吐出圧) & $\mathrm{O}$ & $\mathrm{O}$ \\
\hline & \multicolumn{2}{|c|}{ 変流量 (台数制御 $\rightarrow 1$ 台のみ絞り運転) } & O & O \\
\hline & \multirow{2}{*}{$\begin{array}{l}\text { ヘッダーバイパス } \\
\text { 制御 }\end{array}$} & ヘッダーバイパスあり & 0 & 0 \\
\hline & & ヘッダーバイパスなし & O & 0 \\
\hline \multirow{7}{*}{$\begin{array}{l}\text { 冷却水 } \\
\text { ポンプ }\end{array}$} & \multirow{2}{*}{ 定流量 } & バイパス制御なし & O & O \\
\hline & & バ份 ス制御(下限温度) & $\mathrm{O}$ & $\mathrm{O}$ \\
\hline & \multirow{2}{*}{$\begin{array}{l}\text { 変流量 } \\
(\text { ボンプ } 1 \text { 台) }\end{array}$} & 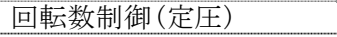 & O & 0 \\
\hline & & 回転数制御 (最小吐出圧) & $\mathrm{O}$ & $\mathrm{O}$ \\
\hline & \multicolumn{2}{|c|}{ 変流量(並列絞り制御) } & $\bigcirc$ & 0 \\
\hline & \multicolumn{2}{|c|}{ 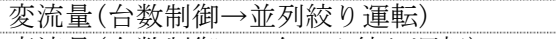 } & 0 & 0 \\
\hline & \multicolumn{2}{|c|}{ 変流量 $($ 台数制御 $\rightarrow 1$ 台のみ絞り運転) } & $\mathrm{O}$ & $\mathrm{O}$ \\
\hline \multirow{2}{*}{$\mathrm{FCU}$} & 定流量 & 二方弁 On/Off 制御 & O & 0 \\
\hline & 変流量 & 二方弁比例制御 (下限負荷率) & O & $x$ \\
\hline
\end{tabular}

・ LCEM ツールは熱負荷計算機能がなく、室モデルが DeST と異 なるため、AHU の境界条件として DeST で算出された室内温

\begin{tabular}{|c|c|c|c|}
\hline 制御 & 制御方法 & LCEM & DeST \\
\hline 並列運転 & 手動切替 & 0 & 0 \\
\hline \multirow{3}{*}{$\begin{array}{l}\text { 台数制御 } \\
\quad \text { (並列絞り運転) }\end{array}$} & 流量による制御 & O & O \\
\hline & 熱量による制御 & 0 & 0 \\
\hline & 自動切替 $* 1$ & 0 & 0 \\
\hline
\end{tabular}
度・湿度、風量を使用した。また、LCEM ッールの FCU モデル ではAHUのような境界条件を与えられないため、DeST で算出 された熱負荷を境界条件とした。
表 1 取り扱い可能なコンポーネントの比較

\begin{tabular}{|c|c|c|c|}
\hline 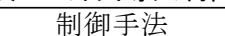 & 設定/判定 & LCEM & DeST \\
\hline 最少外気量運転 & & 0 & 0 \\
\hline \multirow{2}{*}{ 全熱交換器 } & なし & 0 & 0 \\
\hline & あり (全外気運転) & ○ & 0 \\
\hline 外気冷房 & 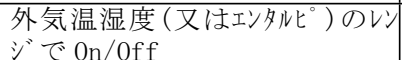 & 0 & 0 \\
\hline 外気カット & On/Off スケジュール & $\mathrm{O}$ & $\mathrm{O}$ \\
\hline
\end{tabular}

\section{表 2 取扱可能な制御方式比較}

\section{表 3 熱源台数制御方式比較}

表 4 空気調和機の給気温度 ・ 湿度制御方式

\begin{tabular}{|c|l|c|c|}
\hline 制御方法 & \multicolumn{1}{|c|}{ 適用システム } & LCEM & DeST \\
\hline 代表室温度による制御 & CAV & $\bigcirc$ & $\bigcirc$ \\
\hline AHU の給気温湿度固定 & VAV ${ }^{* 1}$ & $\bigcirc$ & $\bigcirc$ \\
\hline
\end{tabular}

※1LCEM ツールでは給気温度のロードリセットは自動的に行えない

表 5 外気導入制御方式の対応状況 
- 各熱源機器の特性は機器表の情報をもとに入力した。部分負 荷における性能・特性を整合するために必要な機器特性デー タはLCEM ツールを用いて発生させ、それをDeSTに入力した。

\section{2 モデル建物および空調システムの概要}

比較検討対象とするモデル建物を図-4に示す。モデル建物は、東 京に所在するオフィスビルを想定しており、中央部のコア部を挟み、 南北に執務室を有する平面プランとなっている。空調運転は、6/1 ～9/30、11/1〜3/31 の期間中に行われ、 8 時から 19 時までスケジュ 一ル運転される。（日曜・祝日は除く）

表-6 にシステム設計に用いた年間最大負荷計算結果を示す。空調 システムは、熱源側サブシステムは電気主体システム(遠心冷凍機と 空冷ヒートポンプ (以後空冷 HP) の熱源機器構成による複式ポンプ システム) とガス主体システム (直焚き吸収冷温水機による複式ポン プシステム)の両方を想定し、二次側サブシステムは空調機と FCU からなるシステムを想定した。主な機器表を表-7に、空調システム の配管とダクト系統図を図 -5 に示す。

表-8 に空調システムの制御概要を示す。なお、電気主体システム における夏期の熱源機器の運転順位は、遠心冷凍機、空冷 HP の順に、 設定した。

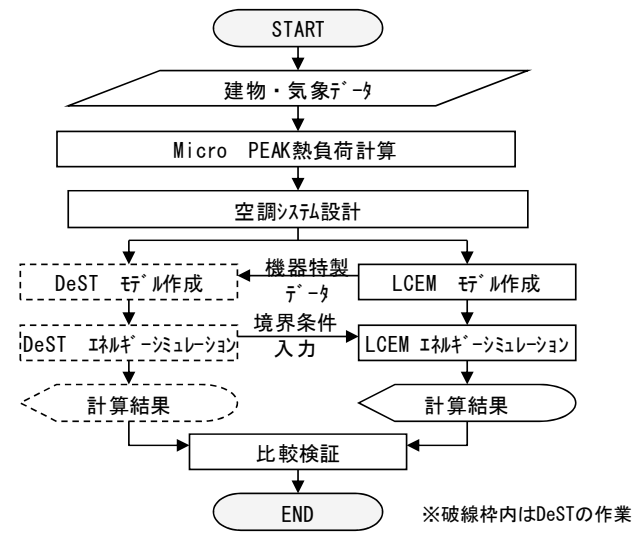

図 3 比較検討の手順

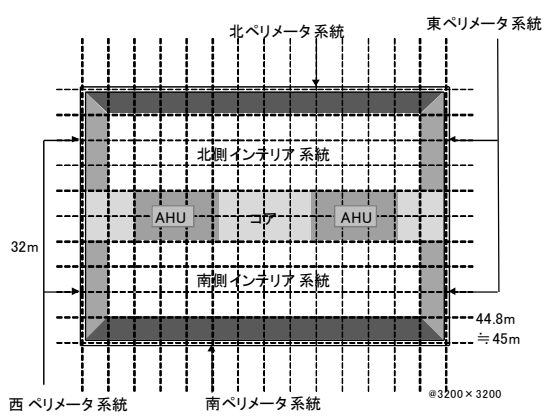

\begin{tabular}{|l|}
\hline 地域: 東京 \\
用途: 事務所 \\
構造 : RC 造 \\
$\quad$ 地上 10 階 \\
延床面積 : \\
$14,400 \mathrm{~m}^{2}$ \\
基準階 $: 1,440 \mathrm{~m}^{2}$ \\
階高 : $4.0 \mathrm{~m}$ \\
天井高 $: 2.7 \mathrm{~m}$ \\
空面積率 $: 0.3$
\end{tabular}

図 4 建物概要および基準階平面図

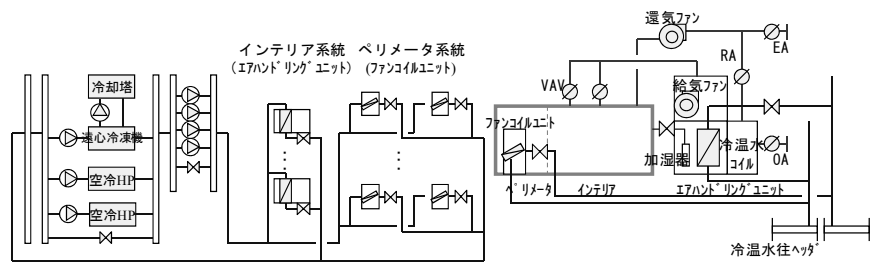

図 5 空調システム系統図 (電気主体システム)

表 6 最大負荷計算結果 (Micro PEAK)

\begin{tabular}{|c|c|c|c|c|c|}
\hline \multicolumn{2}{|c|}{ 基準階 $(\mathrm{kW})$} & \multicolumn{2}{|c|}{ 最上階 $(\mathrm{kW})$} & \multicolumn{2}{c|}{ 建物全体 $(\mathrm{kW})$} \\
\hline 冷房 & 暖房 & 冷房 & 暖房 & 冷房 & 暖房 \\
\hline 121 & 42 & 141 & 72 & 1,230 & 450 \\
\hline
\end{tabular}

\begin{tabular}{|c|c|c|c|}
\hline \multirow{3}{*}{ 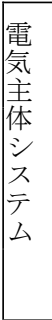 } & 遠心冷凍機 & 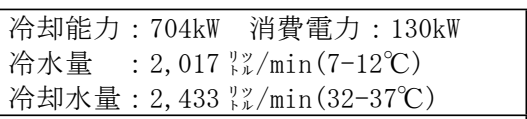 & 1 台 \\
\hline & $\begin{array}{c}\text { 空冷 } \\
\text { ヒートポンプ }\end{array}$ & 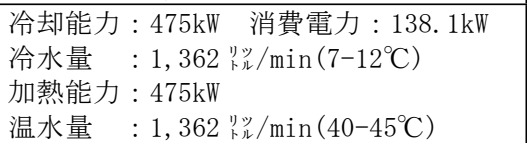 & 2 台 \\
\hline & 冷却塔 & $\begin{array}{l}\text { 開放型 }: 704 \mathrm{~kW} \times 2,433 \text { 紧 } / \mathrm{min}\left(32-37^{\circ} \mathrm{C}\right) \\
\text { 消費電力 }: 4.0 \mathrm{~kW}\end{array}$ & 1 台 \\
\hline \multirow[t]{2}{*}{$\begin{array}{l}\text { ガ } \\
\text { ス } \\
\text { 主 } \\
\text { 体 } \\
シ \\
\text { X } \\
\text { テ } \\
厶\end{array}$} & $\begin{array}{c}\text { 直焚き } \\
\text { 吸収冷温水機 }\end{array}$ & 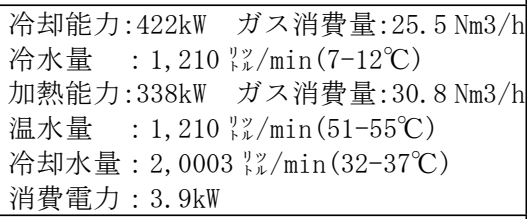 & 3 台 \\
\hline & 冷却塔 & $\begin{array}{l}\text { 開放型 }: 578 \mathrm{~kW} \times 2,000 \text { 坚 } / \mathrm{min}\left(32-37^{\circ} \mathrm{C}\right) \\
\text { 消費電力: } 4.0 \mathrm{~kW} \\
\end{array}$ & 3 台 \\
\hline \multirow{5}{*}{ 次 } & $\begin{array}{l}\text { ユニット型 } \\
\text { 空気調和機 } \\
\text { (基準階) }\end{array}$ & 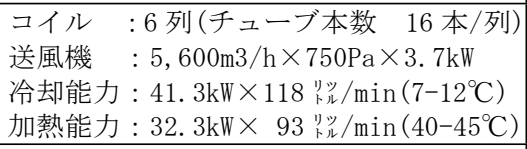 & 20 台 \\
\hline & 還気送風機 & $5,600 \mathrm{~m} 3 / \mathrm{h} \times 210 \mathrm{~Pa} \times 1.5 \mathrm{~kW}$ & 20 台 \\
\hline & 可変風量装置 & 最大風量: $2,800 \mathrm{~m} 3 / \mathrm{h}$ 最小風量: $1,800 \mathrm{~m} 3 / \mathrm{h}$ & 40 台 \\
\hline & $\begin{array}{l}\text { フアンンイイルユニット } \\
\text { (北/南) }\end{array}$ & $\begin{array}{l}\text { 送風量 }: 520 \mathrm{~m} 3 / \mathrm{h} \\
\text { 冷却能力: } 2.0 \mathrm{~kW} \times 6.0 \text { 紧 } / \mathrm{min}\left(7-12^{\circ} \mathrm{C}\right) \\
\text { 加熱能力: } 1.0 \mathrm{~kW} \times 3.0 \text { 监 } / \mathrm{min}\left(40-45^{\circ} \mathrm{C}\right)\end{array}$ & 140 台 \\
\hline & $\begin{array}{l}\text { フアンコイルュニット } \\
\text { （東/西） }\end{array}$ & $\begin{array}{l}\text { 送風量 }: 880 \mathrm{~m} 3 / \mathrm{h} \\
\text { 冷却能力 }: 2.8 \mathrm{~kW} \times 9.0 \text { 紧 } / \mathrm{min}\left(7-12^{\circ} \mathrm{C}\right) \\
\text { 加熱能力 }: 1.0 \mathrm{~kW} \times 3.0 \text { 览 } / \mathrm{min}\left(40-45^{\circ} \mathrm{C}\right)\end{array}$ & 80 台 \\
\hline
\end{tabular}

\section{表 8 空調システム制御概要}

\begin{tabular}{|c|c|c|}
\hline 熱源 & 台数制缺 & $\rightarrow$ 並列絞り運転 \\
\hline 1 次ポンプ & 定流量 & バイパス制御なし \\
\hline 2 次ポンプ & 変流量 & 定圧制御 (回転数制御) \\
\hline 冷却水ポンプ & 定流量 & バイパ 䎺御あり (下限水温 $\left.32^{\circ} \mathrm{C}\right)$ \\
\hline 給気/還気送風機 & 変風量 & 定圧制御 (回転数制御) \\
\hline 空気調和機 & & 給気温度一定 $\left(15^{\circ} \mathrm{C} ）\right.$ \\
\hline 外気導入 & 最小外今 & 量一定制御 $(1,800 \mathrm{~m} 3 / \mathrm{h})$ \\
\hline
\end{tabular}

\section{3 シミュレーション条件}

気象データは、アメダス標準年気象データ(地域; 東京) を利用し た。また、機器特性として、図-6,7 (熱源機器) 図-8, 9 (搬送系機 器）に示寸特性を与えた。計算期間は、空調運転期間である夏期 $6 / 1$ 〜9/30 と冬期 11/1〜3/31 の間とした。

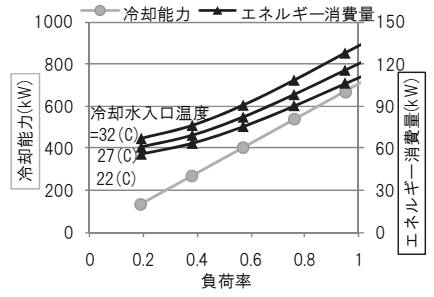

図 6 遠心冷凍機の運転性能 ·特性曲線

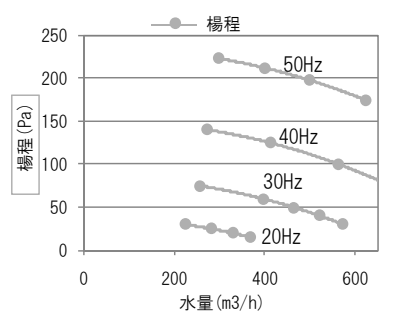

図 8 二次ポンプの特性曲線

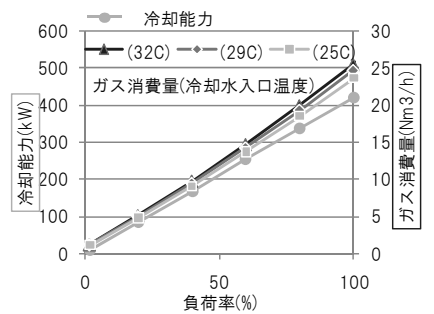

図 7 吸収冷温水機の運転性能 . 特性曲線

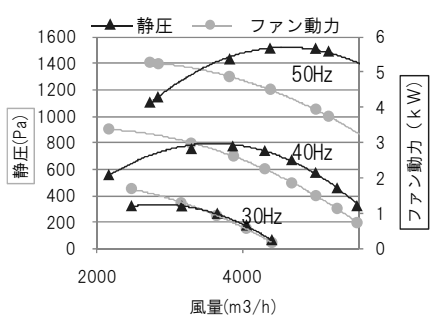

図 9 送風機の特性曲線 


\section{4 比較結果}

モデル建物について LCEM ツール、DeST それぞれ空調シミュレー ションを行った結果比較を示す。

1) システム全体

システム全体および各サブシステムのエネルギー消費量の計算結果 を電気主体システムは図-10 に、ガス主体システムは図-11 に示す。 冷房期間、暖房期間ともに、両者はよく一致しているといえ、DeST が LCEM ツールより最大約 12\%大きくなっている。

\section{2) 熱源}

空冷 HP、吸収冷凍機の機器特性と、熱源機器出力の計算結果を図 -12,13 に示す。図より、両機器ともに、LCEM ツールとDeST の結果 は一致している。夏期における熱源エネルギー消費量はやや LCEM のほうが大きくなっているが、図-14 に示すように、熱源機器出力 の差によるものである。前述したように FCU の室モデルが異なるた めである。
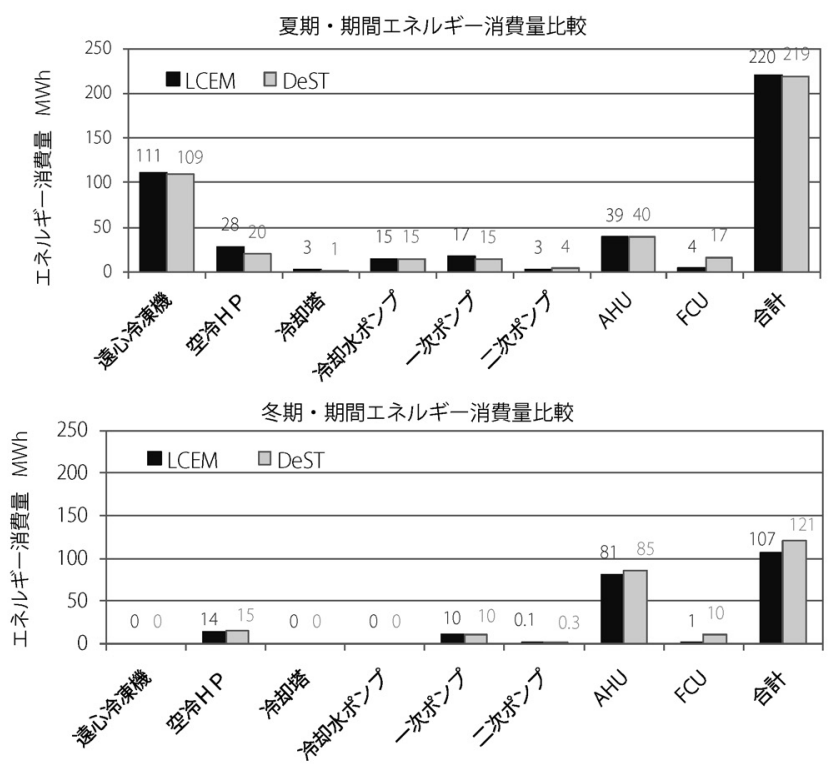

図 10 電気主体システムのシステム全体エネルギー消費量比較
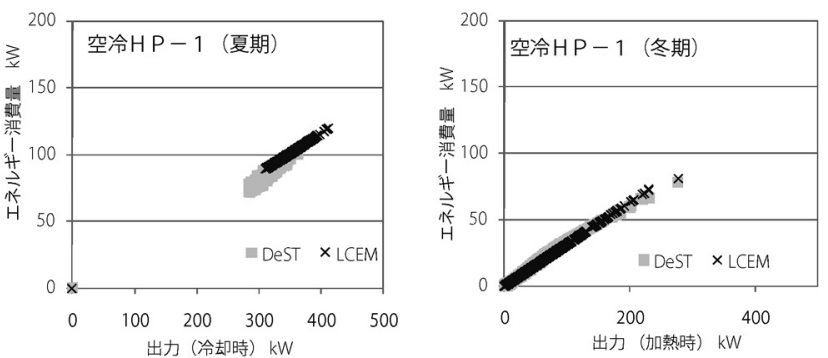

図 12 空冷 HP 特性比較（夏期／冬期）
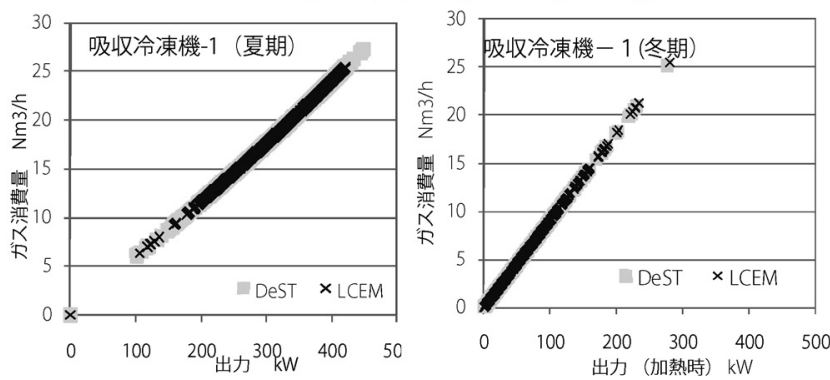

図 13 吸収冷凍機特性比較（夏期／冬期）
3) ポンプ類

図-10,11 に示すように各ポンプのエネルギー消費量はほぼ一致 している。特筆す心゙き、変流量（回転数）制御を採用した二次ポン プ特性を図-15 に示す。二次ポンプ特性は両者一致しているが、流 量において DeST が LCEM ツールより大きくなっている。この差は、 図-17 に示寸、二次側システム (AHU, FCU) のコイル特性の違いによ るものである。

3) AHUまわり

送風機特性の比較を図-16 に示す。両者の送風機特性は一致して いる。

4)FCUまわり

送風機動力は、DeST が LCEM ツールより大きい。(図-10, 11 参照) これは 3 章で述べた LCEM ツールと DeST の FCU 送風機モデルの違い に関連している。

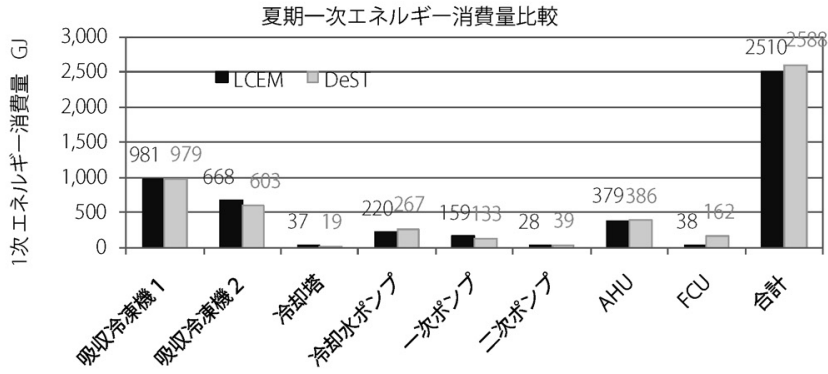

冬期一次エネルギー消費量比較

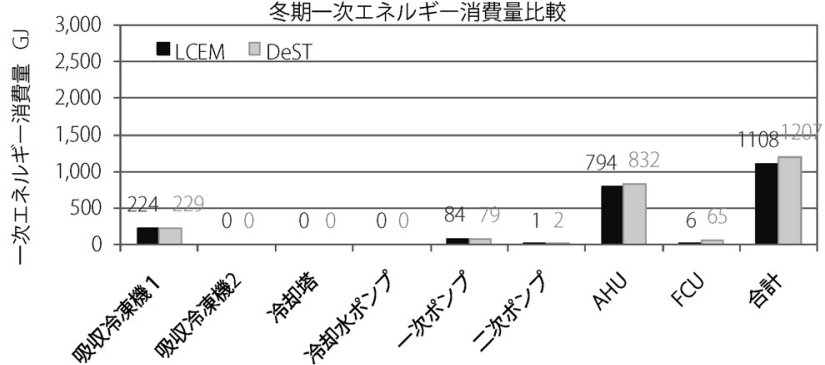

図 11 ガス主体システムのシステム全体エネルギー消費量比較

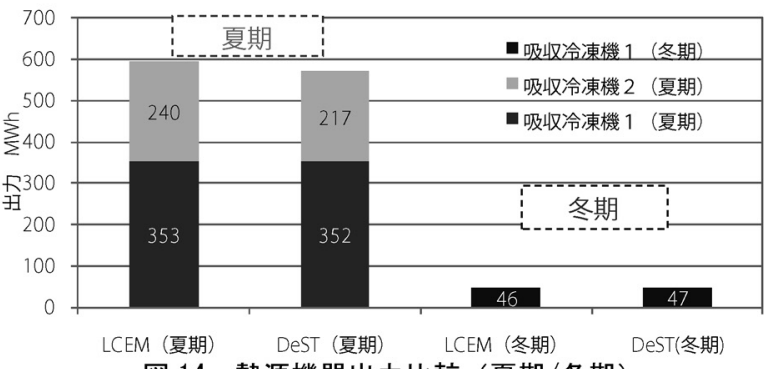

図 14 熱源機器出力比較（夏期/冬期）

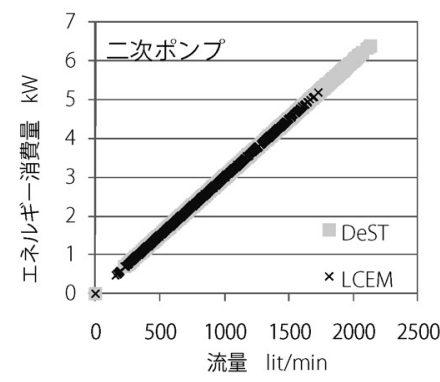

図 15 二次ポンプ特性比較

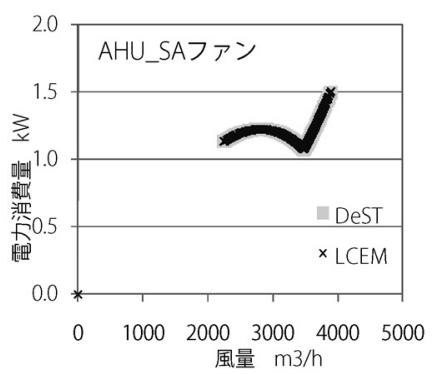

図 $16 \mathrm{AHU}$ 送風機特性比較 

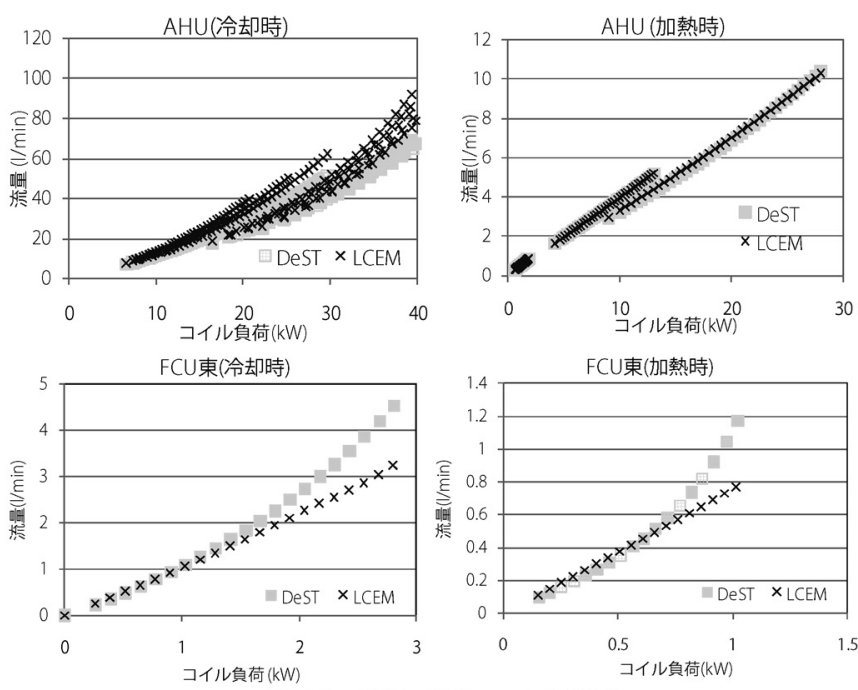

図 17 AHU・FCU コイル特性

\section{5 まとめ}

両ツールを利用する上で、機器特性の整合性をとることが、重要 なポイントであり、整合可能な事項を整合させることができれば、 両者のシミュレーション結果はほぼ一致するといえる。しかし AHU と FCU のコイル特性は完全に合わせることができない。コイルのス ペックなどを合わせたとしても、伝熱計算のモデル化に違いがある ため、同じ特性を有するコイルをシミュレーション上で再現できな い。両ツールを利用する際に、ユーザーはこの点に注意が必要であ る。また、今後のツール開発に生かすべき点でもある。

\section{6. 今後の展開}

今後は、各種熱源システムに対する比較やケーススタディーを行

い、建物のライフサイクルエネルギーマネージメントの見地から、

より有効な活用方法について検討し報告する予定である。

\section{謝辞}

本研究を進めるにあたり、ご指導頂いた (社) 公共建築協会/空調シ ステムシミュレーションツールの国際的評価検討委員会の江教 授, 朱教授, 下田教授はじめ委員会委員諸氏に謝意を表します。

【空調シイテムシシュレーション゙リールの国際的評価検討委員会委員】座長：奥宮 正哉 (名古屋大学), 中原信生 (建築設備コシッショシング協会)、江億 (清華 大学), 朱䁲心 (清華大学), 時田繁 (公共建築協会), 下田吉之 (大阪 大学), 田中英紀 (中部大学), 尹奎英 (名古屋市立大学), 丹羽英治 (日建設計総合研究所), 渡辺剛 (NTT ファシリテイーズ), 鄭明傑 (三晃空 調), 中村紀吉 (東京電力), 濱根潤也 (関西電力), 村西良司 (中部電 力), 市川徹 (東京ガス), 船谷昭夫 (大阪ガス), 草深隆道 (東邦ガ ス), 野村修(建築保全センタ)オブザーバー: 伊藤誠恭, 村山雄介, 神鳥 博俊，鈴木和佳（国土交通省大臣官房官庁営繥部・設備課）

\section{参考文献}

1) 丹羽英治; 動的システムシミュレーションの現状, 空気調和衛生工学会誌, 2003.11

2) Fangting Song:Research on the method and application of HVAC system energy consumption simulation in built large-scale public building，精華大学博士論文, 2009. 12

3) 岡崎徳臣, 奥宮正哉ほか：ライフサイクルエネルギーマネジメントのため の空調システムシミュレーション開発 (第 3 報)、(第 7 報)，空気調和・衛 生工学会学術講演会, 2006

4) Da Yan ほか : DeST-An Intergrated Building Simulation Toolkit Part I:Fundamentals, Build Simulation(2008) 1 pp. 95-110

5) 杉原ほか:ライフサイクルエネルギーマネジメントのための空調システム シミュレーション開発 (第 2 報), 空気調和・衛生工学会学術講演会, 2007 6) DeST User Guide , 2004

7) Exce1 による空調システムシミュレーション〜LCEM ツール Ver. 3 利用 解説 , 社団法人 公共建築協会, 2008
記号一覧

\begin{tabular}{lr}
\hline \hline$B$ : 調整変数 $[\mathrm{W} /(\mathrm{m} \cdot \mathrm{K} \cdot \mathrm{s})]$ & $C, C_{p}:$ 水, 空気の比熱 $[\mathrm{J} /(\mathrm{kg} \cdot \mathrm{K})]$ \\
$C_{1}$ : 負荷率影響係数 $[-]$ & $C_{2}$ : 冷却水還温度影響係数 $[-]$ \\
$C_{3}$ : 冷却水量影響係数 $[-]$ & $C_{4}:$ 冷水温度影響係数 $[-]$ \\
$C_{5}$ : 冷水量影響係数 $[-]$ & $D:$ 調整変数 $[\mathrm{W} /(\mathrm{m} \cdot \mathrm{K} \cdot \mathrm{s})]$ \\
$E:$ エネルギー消費量 $[\mathrm{J}]$ & $e:$ エネルギー消費率 $[-]$ \\
$E^{\prime}$ : 通用熱交換効率 $[-]$ & $E_{g}$ : 全熱交換効率 $[-]$
\end{tabular}

$E_{\text {rated }}$ : 定格エネルギー消費量 $[\mathrm{J}]$ freq : 回転数 $[\mathrm{Hz}]$

$F, F_{y}$ : フィンつきコイルの外側伝熱面積, コイル正面面積 $\left[\mathrm{m}^{2}\right]$

$G:$ 空気の風量 $[\mathrm{kg} / \mathrm{s}] \quad G_{k}(\tau): \tau$ 時刻の $\mathrm{k}$ 室への給気量 $[\mathrm{kg} / \mathrm{s}]$

$G_{k, c a l, \min }(\tau): \mathrm{k}$ 室への実際送風最小給気量 $[\mathrm{kg} / \mathrm{s}]$

$G_{k, c a l, \text { max }}(\tau): \tau$ 時刻の $\mathrm{k}$ 室への実際送風最大給気量 $[\mathrm{kg} / \mathrm{s}]$

$G_{k, \text { max }}(\tau): \tau$ 時刻の $\mathrm{k}$ 室への送風可能な最大給気量 $[\mathrm{kg} / \mathrm{s}]$

$G_{k, \min }(\tau): \tau$ 時刻の $\mathrm{k}$ 室への送風可能な最小給気量 $[\mathrm{kg} / \mathrm{s}]$

$G_{\text {max }}$ : 送風機最大風量 $[\mathrm{kg} / \mathrm{s}] \quad G(\tau): \tau$ 時刻の給気風量 $[\mathrm{kg} / \mathrm{s}]$

$H$ : 楊程 $[\mathrm{Pa}] \quad i_{1}, i_{2}$ :入口空気、出口空気のエンタルピ $[\mathrm{J} / \mathrm{kg}]$ $K f:$ 伝熱係数 $\left[\mathrm{W} /\left(\mathrm{m}^{2} \cdot \mathrm{K} \cdot \mathrm{Row}\right)\right]$

$K_{S}$ : 湿り伝熱面のフィン効率 $\left[\mathrm{W} /\left(\mathrm{m}^{2} \cdot \mathrm{K}\right)\right] \quad m$ : 調整変数 $[-]$

$M T D$ : 対数平均温度差 $[\mathrm{K}] \quad N$ : コイル列数 $[\mathrm{Row}]$

$n:$ 調整変数 $[-]$

$P L R ：$ 部分負荷率 $[-]$

$p:$ 調整変数 $[-]$

$Q_{a}:$ 空気側交換熱量 $[\mathrm{W}]$

$Q:$ 出力 $[\mathrm{W}]$

$Q_{s}(\tau): \tau$ 時刻の室内顕熱負荷 $[\mathrm{W}]$

$t_{1}, t_{2}$ : 入口空気、出口空気の温度 $\left[{ }^{\circ} \mathrm{C}\right]$

$t_{1 S}, t_{2 S}$ : 入口空気、出口空気の設定温度 $\left[{ }^{\circ} \mathrm{C}\right]$

$t_{a, i n}:$ 熱源出口空気温度 $\left[{ }^{\circ} \mathrm{C}\right]$

$t_{c w, o u t}, t_{c w, i n}$ : 冷却塔出口温度、入口温度 $\left[{ }^{\circ} \mathrm{C}\right]$

$t_{c w, f}:$ フリークーリング状態の冷却水往温度 $\left[{ }^{\circ} \mathrm{C}\right]$

$t_{c w, s e t}$ : 強制的にファンを止めた場合の設定温度 $\left[{ }^{\circ} \mathrm{C}\right]$

$t_{k}(\tau): \tau$ 時刻の $\mathrm{k}$ 室の設定温度 $\left[{ }^{\circ} \mathrm{C}\right]$

$\hat{t}_{k}(\tau): \tau$ 時刻の $\mathrm{k}$ 室の自然室温 $\left[{ }^{\circ} \mathrm{C}\right]$

$t_{k, \text { set, } \max }(\tau): \tau$ 時刻の $\mathrm{k}$ 室の設定上限温度 $\left[{ }^{\circ} \mathrm{C}\right]$

$t_{k, \text { set }, \text { min }}(\tau): \tau$ 時刻の $\mathrm{k}$ 室の設定下限温度 $\left[{ }^{\circ} \mathrm{C}\right]$

$t_{k, \text { supply }}(\tau): \tau$ 時刻の $\mathrm{k}$ 室への給気温度 $\left[{ }^{\circ} \mathrm{C}\right]$

$t_{k, \text { supply,min }}(\tau): \tau$ 時刻の $\mathrm{k}$ 室への最小給気温度 $\left[{ }^{\circ} \mathrm{C}\right]$

$t_{k, \text { supply,max }}(\tau): \tau$ 時刻の $\mathrm{k}$ 室一の最大給気温度 $\left[{ }^{\circ} \mathrm{C}\right]$

$t_{r}(\tau): \tau$ 時刻の室内温度 $\left[{ }^{\circ} \mathrm{C}\right] \quad t_{\text {supply }}(\tau): \tau$ 時刻の給気温度 $\left[{ }^{\circ} \mathrm{C}\right]$

$t_{r, \text { supply }}(\tau): \tau$ 時刻の要求給気温度 $\left[{ }^{\circ} \mathrm{C}\right]$

$t_{\text {system,supply }}(\tau): \tau$ 時刻の空調機の吹出し温度 $\left[{ }^{\circ} \mathrm{C}\right]$

$t_{w b, O A}:$ 外気湿球温度 $\left[{ }^{\circ} \mathrm{C}\right] \quad t_{w, i n}$ : 熱源出口水温 $\left[{ }^{\circ} \mathrm{C}\right]$

$t_{w 1}, t_{w 2}$ : コイルの入口、出口水温 $\left[{ }^{\circ} \mathrm{C}\right] \quad V_{y}:$ コイル風速 $[\mathrm{m} / \mathrm{s}]$

$W:$ 水量 $[\mathrm{kg} / \mathrm{s}] \quad W S F$ : 濡れ面係数 $[-]$

$\alpha_{w}:$ コイルの外側 $\left(\right.$ 空気側）熱伝達率 $\left[\mathrm{W} /\left(\mathrm{m}^{2} \cdot \mathrm{K}\right)\right]$

$\eta$ : 効率 $[-] \quad \xi$ : 析湿係数 $[-]$

$\rho, \rho_{w}:$ 空気の比重、水の比重 $\left[\mathrm{kg} / \mathrm{m}^{3}\right]$

$\psi$ : 単位空調熱量の室温への影響度 $\left[\left(\mathrm{m}^{3} \cdot \mathrm{K}\right) /(\mathrm{W} \cdot \mathrm{kg})\right]$

$\Omega_{t, \text { system }}(\tau): \tau$ 時刻に空調機に要求される吹出し温度の範囲

$\omega:$ コイル水速 $[\mathrm{m} / \mathrm{s}]$

[2010 年 2 月 19 日原稿受理 2010 年 4 月 5 日採用決定 $]$ 